\title{
The Effect of Strategic Innovation on Financial Performance in the Industrial Sector
}

\author{
Ni Nyoman Alit Triani \\ Universitas Negeri Surabaya \\ Surabaya, Indonesia \\ nyomanalit@unesa.ac.id
}

\author{
Susi Handayani \\ Universitas Negeri Surabaya \\ Surabaya, Indonesia \\ susihandayani@unesa.ac.id
}

\begin{abstract}
The purpose of this study is to examine whether the innovation strategy can improve the performance of the company. Its innovations consist of product innovation, process innovation, and market innovation. The better innovation strategies undertaken by the company in creating products, production processes and marketing of new products will be able to improve the company's financial performance. This research was designed as causal studies. The research approach used in this study is quantitative at an explanatory level which aims to test the hypothesis of the influence of innovation on the company's financial performance. This study used a sample of 120 companies grouped in industrial sector in 2016. This research analysis uses a multiple linear regression approach. The suitability test of the model is done by assessing the coefficient of determination, simultaneous testing ( $F$ test), and partial testing (Statistic $t$ test). The results of this study indicate that partially product innovation and market innovation affect the financial performance. In the process of model estimation in multiple linear regression, process innovation correlates with two other innovations, so that the process innovation variables are dropped by the system in the estimation process. Product innovation and market innovation significantly affect the financial performance that has positive ROA.
\end{abstract}

Keywords: product innovation, process innovation, and marketing innovation, Return On Asset, Return On Equity.

\section{INTRODUCTION}

Companies in Indonesia today must have competitive advantage in facing economic development in the era of free market competition. In order to have competitive advantage, companies need continuous innovation activities. Porter [1], describes "competitive advantage mainly lies in the value that can be created by the company for its customers". Referring to this theory, studies on business innovation tend to relate to the relationship between innovation in terms of products, markets, labor, culture, and their relation to organizational performance. There are three forms of innovation carried out by the company, namely product, process and market innovation.

Manufacturing innovation strategies can help executive managers in four ways. The first strategy is to establish innovation in products and processes as a competitive priority
[2][3]. Innovation connects activities with competitive competition strategies; like the company's long-term plan, in pursuing its competitive goals. Second, manufacturing innovation strategies direct executive managers to allocate competencies and skills. Third, this strategy forces executive managers to describe the focus and source of future manufacturing innovation [4]; industrial conditions, and internal skills, resources, strengths and weaknesses [5]. Manufacturing innovation strategies can help companies to improve competitive advantage by differentiating their products and creating value for customers (Porter, 1985). The new product or process is different from the existing ones, the company obtains profits as well as guarantees protected from imitation of competitors [6].

Previous research that has succeeded in proving that product innovation is good; processes and markets have an effect on the company's performance, among others those carried out by (Rosli and Sidek 2013) ;; Zahra and Das (1993); Camison and Lopez, 2010; Garvin (1987); Forker et al., (1996); Hult et al. (2004); Bayus et al. (2003); Espallardo and Ballester (2009); Alegre et al., (2006); Varis and Littunen (2010); (Nemetz and Fry, 1988); Morone and Testa (2008; Anderson (2009); Ar and Baki (2011); Johne and Davies (2000); Sandvik (2003); Otero-Neira et al. (2009).

Based on the description above, this study aims to examine the effect of the innovation strategy that is indicated in the three innovation strategies, namely product innovation, process and market for company performance. The difference of this study with previous research is on the indicator variables used in showing the innovation strategy. The product innovation variable will be measured by an indicator called the introduction of new product (NP); technology newness in product (TNP); product differentiation (DP); number of new products (PB); and PU's unique products). Variable innovation process will be indicated by: Research and Development (R \& D) orientation; new technology applications (TB) and new combitation of product materials (NCM). Market innovation will refer to indicators of whether the company has used an online transaction (OT) application; marketing and promotion innovation (IMP); the ability to find new markets (NM); external focus stimulates new ideas and responsive markets (NI \& RM); network, communication with suppliers and customers (NCS \& C). To measure the company's financial performance, this study will use the return on asset (ROA) variable, by controlling the company's characteristics, namely the company's age and company size. 


\section{LITERATURE REVIEW}

According to Zahra and Das (1993) the innovation strategy is very important as a determinant of the company's financial performance, suggesting that the two models are appropriate to see the relationship between the dimensions of innovation strategy and company performance, and show that it is sequential. This model provides additional insight into the inderect contribution of individual dimensions of innovation strategies to company performance.

Rosli and Sidek (2013) found that product innovation and process innovation significantly affect the company's performance where the impact of the previous one is stronger than the last. In addition to consolidating existing theories about the importance of innovation to explain variations in company performance, the findings also inform SMEs and policy makers that innovation is an important factor in entrepreneurial activities today. Further studies should look at how SMEs can calculate the ratio of the benefits of innovation costs and how they choose the source of internal or external innovation before actual innovation is carried out.

Feng et al. (2004) provide new insights about the productivity paradox associated with adopters of KMS, and ensure that KMS adopters really gain competitive advantage over non-adopters. Theirlinck (2017) based on a series of active $\mathrm{R} \& \mathrm{D}$ representatives of companies in Belgium, qualitative comparison analysis shows that financial performance results related to optimal configuration of strategic R \& D decisions depend on the size of the company and on the time lag being considered. Managers in small-sized companies are advised to pay special attention to a more functional and structured R \& D approach in configuring strategic R \& D decisions. To improve medium-term financial performance, managers in medium-sized companies benefit from more attachments to research-oriented activities, more in-house innovation, and increased absorption capacity in a series of strategic R \& D decisions.

1) H1: product innovation is positively related to the company's financial performance

2) H2: process innovation is positively related to the company's financial performance

3) H3: Market innovation is positively related to the company's financial performance.

\section{RESEARCH METHOD}

This research was designed as causal studies (Cooper and Emory, 1995). The research approach used in this study is quantitative at an explanatory level which aims to test the hypothesis of the influence of innovation on the company's financial performance. Data was collected by questionnaire method. The unit of analysis of this study is a business unit. Respondents from this study were managers and employees who worked in a two-year miniman company. The research population is all manufacturing sector entities in the Indonesia Stock Exchange (IDX). The samples in this study were nine manufacturing sectors listed on the Stock Exchange, a total of 120 companies during 2016. Data were collected with questionnaires sent via email and back as many as 120 companies.

The variables used in this study consist of independent variables, namely innovation. The types of innovation discussed consist of product innovation, process innovation, and market innovation. Product innovation consists of five items consisting of: the introduction of new product; introduction of the latest technology in manufactured products (technological newness in product); do product differentiation; number of new products (number of new products); uniqueness of new products uniqueness of new products. The first three items were adopted from the study (Rosli and Sidek 2013) and the next two items were adopted from research from Hernández-Espallardo and Delgado-Ballester (2009). Process innovation consists of three items, namely orientation on research and development ( $\mathrm{R} \& \mathrm{D}$ orientation); the use of new technology and using a combination of materials in business raw materials (the application of new technology and the new combination of material in product. These three items were adopted from research from Rosli and Sidek (2013). Market innovation consists of five items consisting of: using the application of online transaction, innovating marketing and promotion efforts (innovative marketing and promotion), managerial ability to find new products, focusing on external conditions to stimulate new ideas and develop new ideas, and be responsive to market needs (external focus stimulates new idea and responsiveness to market), develops a network of ongoing cooperation and communication with supervisors of raw and customer materials (network, communication with suppliers and customers). Adopted research from Rosli and Sidek (2013), and two slag items Hir adopted from Hurley et al. (1988). Respondents were asked questions about the application of product, process and market innovation strategies, using the five-point linkert scale.

This study uses financial performance in general indicated by Return on Assets (ROA) and Return on Equity (ROE) as the dependent variable. Financial performance is measured using a five-point linkert scale. The control variables used in this study are the characteristics of the individuals surveyed and the characteristics of the company, namely the number of employees (firm's size) and the age of the company (firm's age). An established company (AGE) will have a positive relationship with the level of growth and financial performance (Begley and Boyd, 1986: 12). In this study all variables were measured by questionnaire instrument with linkert scale (5 scales). Furthermore, the number of employees is measured by the number of permanent employees owned by the company. This is indicated by the number of employees from 100 employees to 500 employees. The company's business is measured by the age of the company surveyed from the age of the company 1 year to the company that is more than 5 years old.

The focus of this study is to examine the possibility of a direct influence of the innovation strategy, number of employees, and the age of the company on financial performance. This research analysis uses multiple linear regression approach. The suitability test of the model is done by assessing the coefficient of determination, simultaneous 
testing ( $\mathrm{F}$ test), and partial testing (Statistic t test). The model equation in this study is as follows:

$$
F P_{i}=\alpha_{0}+\sum_{j=1} \beta_{j} K I_{i}+\sum_{k=1} \gamma_{k} K P_{i}+\sum_{l=1} \delta_{l} \operatorname{Inov}_{i}+\varepsilon_{i}
$$

Where:

FP: Financial performance.

This indicator includes return on assets and return on equity KI: Individual characteristics of informants who represent companies.

This includes: age, education, experience (having a training certificate), length of work, and dummy whether the person in question has a leadership position (decision maker in the company or not. In this case, leader $=1$ )

$\mathrm{KP}$ : Characteristics of the company, in the form of the number of employees and the age of the company

Inov: The form of managerial / business innovation carried out by companies where individuals work. This includes: production innovation, process innovation, and market innovation

\section{$\varepsilon=$ Residual in model}

\section{RESULTS AND DISCUSSION}

Before presenting the estimation results of the model used, a description of the data used in this study will be presented first. In general, the overall sample was 120 samples, which were then separated into a sample group of companies that had positive financial performance indicators; namely the value of ROA and ROE ratio is greater than zero (positive) and the sample group that has negative financial performance (ROA) and ROE is smaller than zero. The sample of companies that have positive ROA and ROE is 98 companies and vice versa which have negative financial performance (ROA and ROE) of 31 companies.

The average value of ROA is 0.08 for all samples; where for a sub sample of companies that have good financial performance; average ROA is 0.11 and for sub-samples of companies that have poor financial performance, the average ROA is -0.05 . The same applies to ROE.

The characteristics of the company are divided into: (i) age, ie the year the company stood up to the time of the survey; and (ii) the number of employees working in the company concerned. The business age range surveyed was 2 years and the logarithm of the average number of employees owned in the range of 6-8 employees.

TABLE I. ROA AND ROE PERFORMANCE ESTIMATION

\begin{tabular}{|c|c|c|c|}
\hline \multirow[b]{2}{*}{ Independent Variable } & \multicolumn{3}{|c|}{ ROA dependent variable } \\
\hline & $\begin{array}{c}\text { All } \\
\text { samples }\end{array}$ & $\begin{array}{c}\text { Positive } \\
\text { ROA }\end{array}$ & $\begin{array}{c}\text { Negative } \\
\text { ROA }\end{array}$ \\
\hline Constanta & $\begin{array}{c}-381.7^{*} \\
(226.9) \\
\end{array}$ & $\begin{array}{l}-430.2^{*} \\
(253.2) \\
\end{array}$ & $\begin{array}{c}64.18 \\
(137.7) \\
\end{array}$ \\
\hline \multicolumn{4}{|c|}{ Individual Characteristics } \\
\hline $\begin{array}{c}\text { Age } \\
\text { (in years) }\end{array}$ & $\begin{array}{l}-0.0176^{*} \\
(0.00945)\end{array}$ & $\begin{array}{c}-0.0131 \\
(0.00938)\end{array}$ & $\begin{array}{c}-0.00344 \\
(0.0127)\end{array}$ \\
\hline Education Level & $\begin{array}{l}0.00578 * \\
(0.00332)\end{array}$ & $\begin{array}{c}0.00457 \\
(0.00316) \\
\end{array}$ & $\begin{array}{l}0.000209 \\
(0.00660)\end{array}$ \\
\hline Training Certificate & 0.00157 & 0.00177 & $4.37 \mathrm{e}-05$ \\
\hline
\end{tabular}

\begin{tabular}{|c|c|c|c|}
\hline & $(0.00192)$ & $(0.00215)$ & $(0.00152)$ \\
\hline $\begin{array}{l}\text { Time Spent } \\
\text { (in years) }\end{array}$ & $\begin{array}{l}-0.0494 \\
(0.0441)\end{array}$ & $\begin{array}{l}-0.0490 \\
(0.0615)\end{array}$ & $\begin{array}{r}-0.037 * * \\
(0.0168)\end{array}$ \\
\hline $\begin{array}{l}\text { Being in Charge } \\
\text { (yes = 1) }\end{array}$ & $\begin{array}{c}0.154 \\
(0.141)\end{array}$ & $\begin{array}{c}0.118 \\
(0.166)\end{array}$ & $\begin{array}{l}0.160 * * \\
(0.0701)\end{array}$ \\
\hline \multicolumn{4}{|c|}{ Companies' Characteristics } \\
\hline $\begin{array}{l}\text { Companies' Age } \\
\text { (in years) }\end{array}$ & $\begin{array}{c}-0.00309 \\
(0.0136)\end{array}$ & $\begin{array}{l}-0.0102 \\
(0.0167)\end{array}$ & $\begin{array}{l}0.00455 \\
(0.0135)\end{array}$ \\
\hline Employees Quantity Log & $\begin{array}{l}0.00632 \\
(0.0113)\end{array}$ & $\begin{array}{r}-0.00523 \\
(0.0138)\end{array}$ & $\begin{array}{c}0.0148 \\
(0.0133)\end{array}$ \\
\hline \multicolumn{4}{|c|}{ Companies' Innovation Aspects } \\
\hline Production Innovation & $\begin{array}{l}62.23^{*} \\
(37.02)\end{array}$ & $\begin{array}{l}70.08 * \\
(41.30)\end{array}$ & $\begin{array}{l}-10.21 \\
(22.38)\end{array}$ \\
\hline Market Innovation & $\begin{array}{l}62.00^{*} \\
(36.89)\end{array}$ & $\begin{array}{l}69.94 * \\
(41.14)\end{array}$ & $\begin{array}{l}-10.60 \\
(22.73)\end{array}$ \\
\hline $\begin{array}{l}\text { Combination of Production } \\
\text { and Market Innovation }\end{array}$ & $\begin{array}{l}-10.10^{*} \\
(6.014)\end{array}$ & $\begin{array}{l}-11.39^{*} \\
(6.705)\end{array}$ & $\begin{array}{c}1.684 \\
(3.693)\end{array}$ \\
\hline \multicolumn{4}{|c|}{ Goodness of fit model Indicators } \\
\hline Sample Size & 120 & 98 & 31 \\
\hline $\begin{array}{c}\text { F test } \\
\text { P-value }\end{array}$ & - & $\begin{array}{l}0,79 \\
0,60\end{array}$ & $\begin{array}{c}3,76^{* * * *} \\
0,0005\end{array}$ \\
\hline R-squared & 0.096 & 0.088 & 0.254 \\
\hline
\end{tabular}

\begin{tabular}{|c|c|c|c|}
\hline \multirow{2}{*}{$\begin{array}{c}\text { Independent } \\
\text { Variable }\end{array}$} & \multicolumn{3}{|c|}{ ROE dependent Variable } \\
\hline & $\begin{array}{c}\text { All } \\
\text { samples }\end{array}$ & $\begin{array}{l}\text { Positive } \\
\text { ROE }\end{array}$ & $\begin{array}{l}\text { Negative } \\
\text { ROE }\end{array}$ \\
\hline Constanta & $\begin{array}{l}-805.0 \\
(579.0) \\
\end{array}$ & $\begin{array}{l}-1.005 \\
(648.2)\end{array}$ & $\begin{array}{c}498.9 \\
(755.4)\end{array}$ \\
\hline \multicolumn{4}{|c|}{ Individual Characteristics } \\
\hline $\begin{array}{c}\text { Age } \\
\text { (in years) }\end{array}$ & $\begin{array}{c}-0.047 * * \\
(0.0222)\end{array}$ & $\begin{array}{l}-0.0334 \\
(0.0221)\end{array}$ & $\begin{array}{l}-0.0523 \\
(0.0793)\end{array}$ \\
\hline Education Level & $\begin{array}{c}0.0137 \\
(0.00843)\end{array}$ & $\begin{array}{c}0.00946 \\
(0.00791)\end{array}$ & $\begin{array}{c}0.0283 \\
(0.0417)\end{array}$ \\
\hline Training Certificate & $\begin{array}{c}0.00440 \\
(0.00295)\end{array}$ & $\begin{array}{c}0.00434 \\
(0.00336)\end{array}$ & $\begin{array}{c}0.00460 \\
(0.00798)\end{array}$ \\
\hline $\begin{array}{l}\text { Time Spent } \\
\text { (in years) }\end{array}$ & $\begin{array}{l}-0.0543 \\
(0.0818)\end{array}$ & $\begin{array}{l}-0.0938 \\
(0.0908)\end{array}$ & $\begin{array}{l}-0.0128 \\
(0.156)\end{array}$ \\
\hline $\begin{array}{c}\text { Being in Charge } \\
(\text { yes = 1) }\end{array}$ & $\begin{array}{c}0.330 \\
(0.245)\end{array}$ & $\begin{array}{c}0.294 \\
(0.236)\end{array}$ & $\begin{array}{c}0.189 \\
(0.539)\end{array}$ \\
\hline \multicolumn{4}{|c|}{ Companies' Characteristics } \\
\hline $\begin{array}{l}\text { Companies' Age } \\
\text { (in years) }\end{array}$ & $\begin{array}{l}-0.0598 \\
(0.0383)\end{array}$ & $\begin{array}{l}-0.0620 \\
(0.0462)\end{array}$ & $\begin{array}{l}-0.0775 \\
(0.0787)\end{array}$ \\
\hline Employees Quantity Log & $\begin{array}{c}0.0142 \\
(0.0312)\end{array}$ & $\begin{array}{l}-0.00331 \\
(0.0375)\end{array}$ & $\begin{array}{c}0.0243 \\
(0.0640)\end{array}$ \\
\hline \multicolumn{4}{|c|}{ Companies' Innovation Aspects } \\
\hline Production Innovation & $\begin{array}{c}132.3 \\
(94.65)\end{array}$ & $\begin{array}{c}164.4 \\
(106.0)\end{array}$ & $\begin{array}{l}-79.16 \\
(123.1)\end{array}$ \\
\hline Market Innovation & $\begin{array}{c}130.3 \\
(93.85)\end{array}$ & $\begin{array}{l}(163.1 \\
(105.0)\end{array}$ & $\begin{array}{l}-82.42 \\
(124.9)\end{array}$ \\
\hline $\begin{array}{l}\text { Combination of Production } \\
\text { and Market Innovation }\end{array}$ & $\begin{array}{l}-21.40 \\
(15.33)\end{array}$ & $\begin{array}{l}(10.07 \\
-26.67 \\
(17.16)\end{array}$ & $\begin{array}{c}13.07 \\
(20.35)\end{array}$ \\
\hline \multicolumn{4}{|c|}{ Goodness of fit model Indicators } \\
\hline Sample Size & 120 & 98 & 31 \\
\hline $\begin{array}{c}\text { F test } \\
\text { P-value }\end{array}$ & $\begin{array}{l}1,10 \\
0,36\end{array}$ & - & $\begin{array}{l}1,24 \\
0,22\end{array}$ \\
\hline R-squared & 0.118 & 0.114 & 0.236 \\
\hline
\end{tabular}

Note: the figures in brackets are robust standard errors. Notation for significance numbers: $* * * \mathrm{p}<0.01, * * \mathrm{p}<0.05, * \mathrm{p}<0.1$

Innovations made by the companies surveyed are divided into innovations in production, innovation in processes and innovation in marketing. Survey data stated on a Likert scale are then converted into numbers, so that data can be expressed in a ratio scale. Strongly disagree (STS) answers are given a score of 25; Disagree (TS) answers are given a score of 50; Agree answers (S) are given a score of 75 and very agree answers (SS) are given a score of 100 . For neutral answers (N) given a score of 0 ; because this answer cannot reflect the attitude of agreeing or disagreeing.

Regarding business innovation, the results of the research show that partially the innovation of production and market innovation affect the ROA of the company. There are three types of innovations studied from this study survey, namely 
production innovation, process innovation and marketing innovation. But in the process of estimating the model in multiple linear regressions, process innovation correlates with two other innovations, so that process innovation variables are dropped by the system in the estimation process.

In the table of estimating ROA and ROE performance, production innovation and market innovation significantly affect the financial performance of companies that have positive ROA. This influence relationship is significant at the $10 \%$ level. When combined, iterations of these two innovations; namely the innovation of production and market innovation has changed signs, and is still significant at the level of $10 \%$. This indicates a correlation between these two types of innovation. This type of market innovation and production innovation is irrelevant to affect financial performance; especially companies that have negative ROA and if the company is assessed by ROE performance, both positive and negative ROE. The estimation results give an indication that the company must strive to be selective in innovating, because not all types of innovation are relevant to the needs of the company. In this context, companies engaged in basic industry and basic chemical industry are found to be only relevant in innovating production and marketing innovations and separately.

With regard to the individual characteristics that represent the company, this study finds the following. Increasingly the age of respondents representing the company, related to the lower financial performance. This applies to all study samples, both companies that have good financial performance (positive and negative ROA and ROE). This negative relationship was found to be significant at the level of $10 \%$ testing. Employee education levels show an increase in one level, from undergraduate to master or from master to doctorate owned by basic industrial and chemical industry companies, positively related to the financial performance of all samples, if assessed by the ROA indicator only. On the other hand, if the interviewee is the leader who has the right as a decision maker in the company, the financial performance for the group of companies that have negative ROA is predicted to increase. Meanwhile, none of the indicators found were related to ROE's financial performance, except for the age of the respondents. Also found to have a negative effect.

\section{CONCLUSION}

Innovation is one strategy that can be adapted by companies to improve company performance. One focus of performance that is commonly considered is financial performance. Financial performance reflects the potential flow of earnings received by the company through the type of business it has. This study examines three types of innovation, including production innovation, process innovation and marketing innovation. For industries engaged in basic industry and chemical industry, this study finds that production innovation and marketing innovation have the potential to improve the company's financial performance through the value of return on assets (ROA). Innovations carried out separately show good financial performance, but if innovation is

carried together in these two types of innovation, it can lead to counter effects on ROA.

\section{REFERENCES}

[1] M. Porter, Ladvantage concurrentiel. pp. 7-200.InterEditions, 1986.

[2] J. E. Ettlie, What Make a Manufactur Firm Innovative? Academy of Management Executive. 4(4), pp. 7-20, 1990.

[3] G. Leong., D. Snyder, and P. Ward, Research in the Process and Content of Manufacturing Strategy, Omega, 18(2), pp. 109-122, 1990.

[4] R. A. Burgelman, and L. R. Sayles, Inside Corporate Innovation, Free Press, New York, 1986

[5] Rosenthal, S. R. 1984. Progress Toward the factory of the future. Journal of Operations Management , 4(3), pp. 203-229

[6] Zahra, S. \& Das, S., 1993. Innovation strategy and financial performance in manufacturing companies: An empirical study. Production and Operations Management, 2(I), pp.15-37.Available at: http://onlinelibrary.wiley.com/doi/10.1111/j.19375956.1993.tb00036.x/abstract.

[7] Rosli, M.M. \& Sidek, S., 2013. he Impact of Innovation on the Performance of Small and Medium Manufacturing Enterprises: Evidence from Malaysia. Journal of Innovation Management in Small \& Medium Enterprise, 2013, pp.1-16. Available at: http://www.ibimapublishing.com/journals/JIMSME/2013/885666/88566 6.html.

[8] Teirlinck, P., 2017. Configurations of strategic R \& D decisions and financial performance in small-sized and medium-sized firms. Journal of Business Research, 74, pp.55-65. Available at: http://dx.doi.org/10.1016/j.jbusres.2017.01.008.

[9] Hurley, R.F. et al., 1998. Innovation, Learning: An Organizational and Empirical Integration Examination. Journal of Marketing, 62(3), pp.4254.

[10] Feng, K.C., Chen, E.T. \& Liou, W.C., 2004. Implementation of knowledge management systems and firm performance: An empirical investigation. Journal of Computer Information Systems, 45(2), pp.92104.

[11] Hernández-Espallardo, M. \& Delgado-Ballester, E., 2009. Product innovation in small manufacturers, market orientation and the industry's five competitive forces. European Journal of Innovation Management, 12(4), pp.470-491. Available at: http://www.emeraldinsight.com/doi/10.1108/14601060910996927.

[12] Hult, G. T. M., Hurley, R. F. \& Knight, G. A. (2004). "Innovativeness: Its Antecedents and Impact on Business Performance," Industrial Marketing Management, 33 (5), 429-38

[13] Alegre, J., Lapiedra, R. \& Chiva, R. 2006. A Measurement Scale for Product Innovation Performance. European Journal of Innovation Management, 9 (4), 333-346.

[14] Anderson, A., Wahab, K. A., Amin, H \&; Chong, R. 2009. Firm Performance: An Analysis from the Theory of Innovation. Australian Graduate School Entrepreneurship. [Online], [Retrieved July 29, 2012], http://www.swinburne.edu.au/lib/ir/online conferences/agse2009/000162.pdf

[15] Ar, I. M. \& Baki, B. 2011. Antecedents and Performance Impacts of Product versus Process Innovation: Empirical Evidence from SMEs Located In Turkish Science and Technology Parks. European Journal of Innovation Management, 14 (2), 172-206.

[16] Bayus, B. L., Erickson, G. \& Jacobson, R. 2003. The Financial Rewards of New Product Introductions. Management Science. 49 (2). 197-210.

[17] Camison, C. \& Lopez, A. V. 2010. An Examination of the Relationship between Manufacturing Flexibility and Firm Performance: The Mediating Role of Innovation. International Journal of Operations \& Production Management, 30(8), 853-878

[18] Espallardo, M. H. \& Ballester, E. D. 2009. Product Innovation in Small Manufacturers, Market Orientation and the Industry's Five Competitive Forces: Empirical Evidence from Spain. European Journal of Innovation Management. 12 (4), 470-491. 
[19] Forker, L. B., Vickery, S. K. \& Droge, C. L. M. 1996. The Contribution of Quality to Business Performance. International Journal of Operations and Production Management. 16 (8), 44-62

[20] Gatignon, H. \& Xuereb, J.- M. 1997. Strategic Orientation of the Firm and New Product Performance. Journal of Marketing Research. 34 (1), 77-90.

[21] Johne, A. \& Davies, R. 2000. Innovation in Medium-Sized Insurance Companies: How Marketing Adds Value. International Journal of Bank Marketing. 18 (1), 6-14

[22] Morone, P. \& Testa, G. (2008). "Firms Growth, Size and Innovation an Investigation Into: The Italian Manufacturing Sector," Economics of
[23] Nemetz, P. L. \& Fry, L. W. 1988. Flexible Manufacturing Organizations: Implications for Strategy Formulation and Organization Design. Academy of Management Review. 13 (4), 627-638

[24] Otero-Neira, C., Lindman, M. T. \& Fernández, M. J. 2009. Innovation and Performance in SME Furniture Industries: An International Comparative Case Study. Marketing Intelligence \& Planning. 27 (2), 216232 